\title{
Distribusi Unsur Hara di Dalam Tanah dan Biomassa Tegakan Jati Berumur 8 tahun di Teluk Pandan Kabupaten Kutai Timur
}

\author{
Veronika Murtinah ${ }^{1}$ dan Liris Lis Komara ${ }^{2}$ \\ 1,2 Program Studi Kehutanan, Sekolah Tinggi Pertanian Kutai Timur, Jl. Soekarno \\ Hatta, No. 01, Sangatta, Kutai Timur, Kalimantan Timur \\ 1email: veronikamurtinah@gmail.com
}

\begin{abstract}
The success of forest plantation development has consequences for the selection of species of high economic value and attention to site factors, especially related to nutrient distribution to soil and biomass. The study was conducted on stands of teak plantations aged 8 years in the Teak Plantation area of Teluk Pandan East Kutai. The aim of the study was to determine the amount of nutrient distribution in the soil and the biomass of teak stands. The research was conducted by measuring the amount of nutrients that accumulated in the soil and the amount of nutrients that accumulated in the biomass component of teak stands (stems, branches + twigs, leaves, bark) at 8 years old. Based on the results of this study, it was found that the elements of $P$ and $K$ are the most critical nutrients compared to other nutrients, because almost all of them are already in the vegetation. In addition, nutrients that need attention are Ca and Mg. $N$ nutrients are almost partially in the stands.
\end{abstract}

Keywords: biomass, soil, teak, plantation forest

\begin{abstract}
ABSTRAK
Keberhasilan pembangunan hutan tanaman memiliki konsekuensi terhadap pemilihan jenis yang bernilai ekonomi tinggi dan memperhatikan faktor tapak, terutama bertalian dengan distribusi hara pada tanah dan biomassa. Penelitian dilaksanakan pada tegakan jati berumur 8 tahun di areal tanaman jati masyarakat di Teluk Pandan, Kutai Timur. Tujuan penelitian adalah untuk mengetahui jumlah distribusi hara di dalam tanah dan biomassa tegakan jati. Penelitian dilakukan dengan mengukur jumlah hara yang berakumulasi di dalam tanah dan jumlah hara yang berakumulasi pada komponen biomassa tegakan jati (batang, cabang+ranting, daun, kulit kayu) pada umur 8 tahun. Berdasarkan hasil penelitian ini, diketahui bahwa unsur $\mathrm{P}$ dan $\mathrm{K}$ merupakan unsur hara yang paling kritis dibandingkan dengan unsur hara lainnya, sebab hampir seluruhnya telah berada dalam vegetasi. Selain itu unsur hara yang perlu mendapat perhatian adalah Ca dan Mg. Unsur hara $\mathrm{N}$ hampir sebagian sudah berada di dalam tegakan.
\end{abstract}

Kata kunci: biomassa, tanah, jati, hutan tanaman

\section{Pendahuluan}

Hutan tanaman merupakan suatu konsep pembangunan hutan yang ditujukan untuk mengatasi berbagai masalah yang bermuara pada terciptanya suatu ekosistem yang berkelanjutan (lestari) sesuai dengan peran sosial-ekonomi sumberdaya hutan yang bersangkutan. Permasalahan kesejangan antara jumlah produksi dan konsumsi kayu sebagai akibat pertambahan jumlah penduduk dan berkurangnya luas hutan (degradasi hutan dan lahan kristis) telah menjadi acuan bagi pemerintah untuk menuangkan kedalam kebijakan-kebijakannya, antara lain bahwa hingga tahun 2025, Kementerian Kehutanan memproyeksikan untuk mengembangkan hutan tanaman seluas 25.615.492 ha, terdiri atas 3.989.738 ha HTI, 6.230 ha Hutan Tanaman Rakyat (HTR), 1.360.279 ha melalui Gerakan Rehabilitasi Hutan dan Lahan (Gerhan), 1.301.684 ha non Gerhan dan 2.733.791 ha hutan rakyat. Tantangan utama pembangunan hutan tanaman adalah produktivitas dan nilai 
ekonomi kehutanan (Anonim, 2010), sehingga pemilihan jenis untuk hutan tanaman harus mengutamakan jenis-jenis yang bernilai ekonomi tinggi dan sesuai dengan kondisi tapak sehingga layak, baik secara ekologi maupun ekonomi.

Jenis jati (Tectona grandis Linn.f) telah dikenal memiliki nilai ekonomi yang tinggi, memiliki daur yang lebih panjang dibandingkan dengan beberapa jenis hutan tanaman lainnya dan sisi keunggulan lainnya, sehingga lebih berperan dalam konservasi dan mitigasi perubahan iklim. Studi pendahuluan telah menunjukkan bahwa jati memiliki prospek yang baik untuk dikembangkan di Kalimantan Timur (Widyasasi, 2005; Marjenah, 2008, 2010; Murtinah dkk, 2015). Beberapa hal menjadi catatan penting dan perlu studi lebih lanjut, antara lain terkait faktor tapak (kondisi edafis dan klimatis) di Kalimantan Timur yang berbeda dengan tapak tanaman jati yang telah dikenal sebelumnya, seperti di Pulau Jawa. Faktor klimatis merupakan kondisi alami yang sulit sekali untuk dikelola, sebaliknya faktor edafis/tanah, khususnya pengelolaan hara, yaitu distribusi hara di dalam tanah dan tegakan menjadi penting untuk diteliti guna mendukung keberhasilan hutan tanaman. Dengan mengetahui distribusi hara pada berbagai umur diharapkan dapat menjadi acuan bagi pengambilan keputusan terkait teknik silviklutur hutan tanaman jati, khususnya manajemen hara. Hasil penelitian diharapkan dapat menunjang keberhasilan pembangunan hutan tanaman jati, baik berupa Hutan Tanaman Industri maupun berupa hutan tanaman rakyat, yang memperhatikan prinsip-prinsip pengawetan tanah sebagai faktor produksi.

\section{Metodologi Penelitian}

\section{Waktu dan Lokasi}

Penelitian dilaksanakan selama 5 bulan, meliputi pengambilan sampel tanah dan biomassa di areal tanaman jati masyarakat di wilayah kecamatan Teluk Pandan, Kabupaten Kutai Timur dan analisis sifat fisik dan kimia dilaksanakan di Laboratorium Tanah Fakultas Kehutanan Universitas Mulawarman, Samarinda.

\section{Alat dan Bahan}

Peralatan yang digunakan dalam penelitian ini adalah:

a) GPS (Global Positioning System) untuk mengetahui titik koordinat areal penelitian.

b) Kompas untuk menentukan arah plot.

c) Pita dengan warna mencolok untuk pembatas plot.

d) Clinometer untuk mengukur tinggi pohon.

e) Phi-band untuk mengukur diameter pohon.

f) Cangkul untuk menggali lubang penampang/profil tanah.

g) Meteran $50 \mathrm{~m}$ untuk membuat plot dan meteran $5 \mathrm{~m}$ untuk mengukur kedalaman penampang/tanah, ketebalan dan batas lapisan (horizon). 
h) Pisau cutter untuk menandai batas lapisan tanah dan merapikan sampel tanah di ring sampel.

i) Ring sampel (tabung sampel) tanah untuk mangambil contoh tanah utuh.

j) Timbangan kapasitas $25 \mathrm{Kg}$ dan $2 \mathrm{Kg}$ untuk menimbang sampel komponen pohon di lapangan.

k) Gergaji mesin untuk menebang pohon contoh dan memotong cakram batang.

I) Plastik sampel tanah untuk menyimpan sampel tanah komposit.

m) Spidol permanen untuk menulis label pada sampel tanah.

n) Kamera sebagai alat dokumentasi di lapangan

o) Komputer untuk pengolahan data

Bahan yang digunakan dalam penelitian ini adalah sampel tanah dan sampel komponen pohon yang akan dianalisis di laboratorium tanah, peta tanah dan peta lainnya untuk mendukung penelitian.

\section{Prosedur Penelitian}

Menentukan lokasi penelitian berdasarkan kondisi tegakan (kerapatan dan kesehatan tanaman) dan assesibilitas (tersedianya jaringan jalan). Membuat plot penelitian menggunakan meteran $50 \mathrm{~m}$, sisi-sisinya dibatasi dengan pita, posisi geografisnya ditentukan dengan alat GPS (global positioning system) dan untuk penentuan arah plot digunakan kompas. Semua pohon di dalam plot diberi nomor pohon menggunakan pita plastik yang ditempel menggunakan stappler tembak. Pengukuran diameter pohon setinggi dada (dsd/dbh) menggunakan pita ukur, pengukuran tinggi total pohon menggunakan clinometer dan galah/tongkat setinggi 4 meter.

Mengambil sampel tanah untuk uji sifat fisik tanah dengan membuat 1 profil tanah pada plot penelitian. Dari profil tanah tersebut diambil sampel tanah menggunakan ring sampel untuk menentukan sifat fisik tanah (bulk density), sebanyak 3 ring di tiap kelas kedalaman 0-30 cm, 30-60 cm, 60-100 cm. Pengambilan sampel untuk sifat kimia tanah dilakukan secara komposit dari 5 titik pengambilan sampel yang terdiri atas 1 titik pada profil tanah dan 4 titik lainnya diambil dengan radius sekitar $12,5 \mathrm{~m}$ dari profil tanah. Tanah yang diambil dari kelima titik tersebut dicampur lalu diambil sampel $\pm 1 \mathrm{~kg}$.

Mengambil sampel biomassa dilakukan pada komponen-komponen yang berada di atas permukaan tanah (above ground biomass), meliputi batang, cabang, daun dan kulit. Penetapan pohon-pohon contoh untuk uji kimia dilakukan dengan mengukur diameter (d) dan tinggi (h) seluruh individu pohon dalam plot. Penetapan batas tiap strata dilakukan dengan menggunakan metode Calculation of Stratum Boundariest by the Cumulative $f(y)$ (Cochran, 1977). Pohon-pohon yang dipilih sebagai pohon contoh dalam tiap strata adalah pohon yang memiliki nilai $d^{2} h$ rataan untuk strata tersebut. Tiap strata ditebang sebanyak 1 pohon contoh, sehingga dari 3 strata ditebang sebanyak 3 pohon contoh. Penebangan 
dilakukan terhadap pohon-pohon contoh, selanjutnya pengambilan sampel komponen pohon yang representatif. komponen cabang dan daun diambil dengan memperhatikan kedudukannya secara vertikal dan horisontal. Komponen batang dan kulit, diambil dengan dua cakram setebal $5 \mathrm{~cm}$, satu buah di pangkal dan satu buah di sekitar ujung batang, sehingga dapat dihitung volume dengan persamaan sebagai berikut:

$$
\mathrm{V}=1 / 4 \pi \frac{(D 1+D 2)^{2}}{2} \times L
$$

Keterangan: D1 = Diameter cakram (disk) 1; D2 = Diameter (cakram disk) 2; $\mathrm{L}=$ Panjang batang antar disk 1 (base) dan disk 2 (top)

Untuk memperoleh berat kering contoh komponen tegakan dilakukan dengan mengambil contoh komponen segar yang representatif dan dikeringkan dalam oven pada suhu $60-85^{\circ} \mathrm{C}$ hingga beratnya konstan. Berat kering tiap komponen pohon dihitung dengan rumus sebagai berikut:

$$
d w=\frac{f w}{s f w} \times s d w
$$

Keterangan: $\mathrm{dw}=$ Berat kering (dry weight); $\mathrm{Fw}=$ Berat basah (fresh weight); $\mathrm{sdw}=$ Berat kering contoh (sample dry weight); sfw = Berat basah contoh (sample fresh weight).

Total biomassa merupakan penjumlahan biomassa tiap komponen pohon, selanjutnya dilakukan konversi ke dalam satuan berat per hektar (ton/ha). Data disajikan dalam bentuk tabel dan grafik.

Uji kimia komponen tegakan untuk mengetahui konsentrasi Nitrogen dan Fosfor dilakukan menurut metode Hesse (1971); Kalium, Kalsium dan Magnesium (Atomic Absorption Spectrophotometer pada panjang gelombang masing-masing 766,5 nm, 489,5 $\mathrm{nm}$ dan $245,2 \mathrm{~nm}$ ).

\section{Analisis Data}

Unsur hara di dalam tegakan jati dihitung dengan mengalikan berat kering komponen pohon dengan konsentrasi sampel biomassa sehingga diperoleh satuan kg/ha. Berdasarkan data tersebut kemudian disusun informasi distribusi hara di dalam tanah dan tegakan secara kuantiatif (absolut) dan proporsional (\%) di setiap plot penelitian dalam bentuk grafik.

\section{Hasil dan Pembahasan}

\section{Gambaran Umum Lokasi Penelitian}

Areal tanaman jati masyarakat terletak di Kecamatan Teluk Pandan, Kabupaten Kutai Timur, Provinsi Kalimantan Timur. Secara geografis areal tersebut berada pada titik 


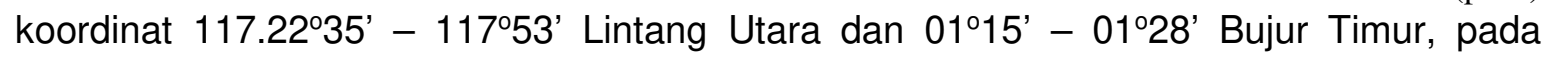
ketinggian 5-100 m di atas permukaan laut, dengan kelerengan >20\% (agak curam)

Berdasarkan kriteria Schmidt dan Ferguson, iklim di areal penelitian termasuk tipe iklim A, jumlah curah hujan tahunan berkisar antara 1.700-2000 mm. Curah hujan relatif tinggi umumnya terjadi di bulan November-Mei, sedangkan pada bulan Juni-Oktober secara umum curah hujannya rendah.

\section{Bulk Density (Kerapatan Lindak) dan Konsentrasi Hara Tanah}

Hasil analisis sifat fisik tanah yaitu bulk density (kerapatan lindak) dan konsentrasi hara di dalam tanah disajikan dalam tabel berikut ini:

Tabel 1. Bulk Density (KerapatanLindak) Dan Konsentrasi Hara Tanah

\begin{tabular}{|c|c|c|c|c|c|c|}
\hline \multirow{2}{*}{$\begin{array}{c}\text { Kedalaman } \\
\text { Tanah } \\
(\mathrm{cm})\end{array}$} & \multirow{2}{*}{$\begin{array}{c}\text { BD } \\
\left(\mathrm{gr} / \mathrm{cm}^{3}\right)\end{array}$} & \multicolumn{5}{|c|}{ Konsentrasi Hara Tanah } \\
\hline & & $\begin{array}{c}\mathbf{N} \\
(\%)\end{array}$ & $\begin{array}{c}\mathbf{P} \\
\text { (ppm) }\end{array}$ & $\begin{array}{c}\mathrm{K} \\
(\mathrm{ppm})\end{array}$ & $\begin{array}{c}\mathrm{Ca} \\
(\mathrm{ppm})\end{array}$ & $\begin{array}{c}\mathrm{Mg} \\
(\mathrm{ppm})\end{array}$ \\
\hline $0-30$ & $1,33(\mathrm{~S})$ & 0,13 & 3,31 & 37,11 & 2,99 & 0,97 \\
\hline $30-60$ & $1,40(\mathrm{~S})$ & 0,05 & 2,67 & 20,20 & 1,89 & 0,37 \\
\hline $60-100$ & $1,48(\mathrm{~T})$ & 0,04 & 2,67 & 22,13 & 1,87 & 0,34 \\
\hline
\end{tabular}

Bobot isi adalah bobot kering suatu volume yang terisi bahan padat dan volume ruangan (ruang pori tanah) yang dinyatakan dalam $\mathrm{gr} / \mathrm{cm}^{3}$ (Hardjowigeno, 1989). Semakin tinggi BD, menunjukkan tanah semakin padat (Imoro et al, 2012) dan semakin rendahnya ruang pori tanah (Odewumi et al, 2013). Tanah dengan bobot isi rendah, akar tanaman akan lebih mudah berkembang (Hardjowigeno, 1987), sebaliknya BD tinggi akan menghalangi pergerakan air dan penetrasi perakaran (Singer dan Munns, 2002 dalam Imoro et al, 2012). Berdasarkan Tabel 1 dapat diketahui nilai BD di areal penelitian antara 1,33 - 1,48 $\mathrm{gr} / \mathrm{cm}^{3}$ (sedang-tinggi). Pola/kecederungan BD semakin meningkat dengan bertambahnya kedalaman tanah. Hal ini terkait dengan peningkatan kadar liat, dengan semakin bertambahnya kedalaman tanah, maka kadar liatnya cenderung meningkat sebagai akibat proses pembentukan tanah.

Konsentrasi hara $\mathrm{N}$ di dalam tanah pada plot penelitian memiliki kecenderungan semakin menurun dengan semakin bertambahnya kedalaman tanah. Hal ini di duga dipengaruhi oleh kandungan bahan organik yang lebih tinggi di permukaan tanah dibandingkan dengan lapisan tanah di bawahnya. Konsentrasi $P$ cenderung menurun dengan bertambahnya kedalaman tanah. Hal tersebut patut diduga terjadinya karena menurunnya kandungan bahan organik tanah dan bahan induk. Konsentrasi $\mathrm{K}$ cenderung fluktuatif dengan bertambahnya kedalaman tanah, kedalaman 30-60 cm nilainya paling rendah. Unsur $\mathrm{K}$ merupakan unsur hara yang sumber utamanya adalah mineral-mineral primer. Dengan demikian patut diduga terjadi pelapukan intensif batuan yang menghasilkan ion $\mathrm{K}^{+}$yang sedikit. Unsur hara $\mathrm{Ca}$ dan $\mathrm{Mg}$ memiliki kecenderungan yang sama, yaitu secara umum cenderung menurun dengan bertambahnya kedalam tanah. 


\section{Kandungan Hara Tanah}

Kandungan hara tanah adalah hasil perkalian antara konsentrasi hara dan berat kering tanah dalam satuan berat per satuan luas $(\mathrm{kg} / \mathrm{ha})$. Secara umum unsur hara yang paling banyak berada di dalam tanah adalah $\mathrm{Ca}$, diikuti $\mathrm{N}, \mathrm{Mg}, \mathrm{K}$ dan paling sedikit $\mathrm{P}$. $\mathrm{N}$ dalam tanah berasal dari hasil dekomposisi bahan organik sisa-sisa tanaman maupun binatang (Hardjowigeno,1987), pemupukan (terutama urea dan ammonium nitrat) dan air hujan (Hanafiah, 2005). Dalam Tabel 2 tampak terjadinya penurunan kandungan $\mathrm{N}$ dari kelas kedalaman 0-30 cm ke 30-60 cm. Hal tersebut lebih disebabkan oleh konsentrasi $\mathrm{N}$, sedangkan meningkatnya di kedalaman 60-100 cm lebih dipengaruhi oleh BD dan ketebalan lapisan tanah.

Tabel 2. Kandungan Hara Tanah $(\mathrm{kg} / \mathrm{ha})$

\begin{tabular}{cccrcc}
\hline $\begin{array}{c}\text { Kelas Kedalaman } \\
\text { Tanah }(\mathbf{c m})\end{array}$ & $\mathbf{N}$ & $\mathbf{P}$ & $\mathbf{K}$ & $\mathbf{C a}$ & $\mathbf{M g}$ \\
\hline $0-30$ & 4914,0 & 12,5 & 140,3 & 4520,9 & 880,0 \\
$30-60$ & 1995,0 & 10,7 & 80,6 & 3016,4 & 354,3 \\
$60-100$ & 2144,0 & 14,3 & 118,6 & 4009,3 & 437,4 \\
\hline Total & 9053,0 & 37,5 & 339,5 & 11546,6 & 1671,7 \\
\hline
\end{tabular}

Sumber utama P larutan tanah, disamping dari pelapukan bahan induk juga berasal dari mineralisasi P-organik hasil dekomposisi sisa-sisa tanaman yang mengimobilisasikan $P$ dari larutan tanah dan hewan (Hanafiah, 2005). Penurunan jumlah kandungan $P$ dari kelas kedalaman tanah 0-30 cm ke 30-60 cm lebih disebabkan oleh perbedaan konsentrasi $P$ dalam tanah, selanjutnya peningkatan pada kedalaman 60-100 cm lebih disebabkan oleh ketebalan tanahnya karena konsentrasinya sama. Penurunan $\mathrm{P}$ di permukaan tanah terkait dengan produksi bahan organik yang jatuh pada lantai hutan.

Unsur $\mathrm{K}$ merupakan unsur hara makro kedua setelah $\mathrm{N}$ yang paling banyak diserap oleh tanaman (Hanafiah, 2005). Sumber K dalam tanah adalah mineral-mineral primer tanah (felspar, mika dan lain-lain) dan pupuk buatan (ZK) (Hardjowigeno, 1987). Dalam Tabel 2 diketahui $\mathrm{K}$ paling sedikit pada kelas kedalaman tanah 30-60 cm. Hal tersebut disebabkan oleh menurunya konsentrasi hara pada kelas kedalaman tersebut, sedangkan pada kelas kedalaman tanah 60-100 cm lebih dipengaruhi oleh BD dan ketebalan horison. Secara vertikal di dalam tanah terjadi peningkatan jumlah kandungan $\mathrm{K}$ dengan semakin menjauhi permukaan, seperti halnya $\mathrm{N}$ dan $\mathrm{P}$.

$\mathrm{Ca}$ dalam tanah berasal dari mineral-mineral primer (plagioklas), Karbonat $\left(\mathrm{CaCO}_{3}\right.$ dan $\left.\mathrm{CaMg}\left(\mathrm{CO}_{3}\right)_{2}\right)$, garam-garam sederhana $\left(\mathrm{CaSO}_{4}\right.$ dan Ca Fosfat) (Hardjowigeno, 1987). Seperti halnya $\mathrm{N}$, jumlah $\mathrm{Ca}$ dalam tanah pada plot penelitian ini jumlahnya jauh lebih besar daripada unsur lainnya. Besarnya jumlah Ca berasal dari mineral batuan induk penyusun tanah. Seperti halnya N, P dan K terdapat kecenderungan peningkatan jumlah Ca seiring dengan bertambahnya kedalaman tanah. Jumlah $\mathrm{Ca}$ di lapisan tanah permukaan relatif lebih banyak jika dibandingkan dengan unsur $\mathrm{P}$ dan $\mathrm{K}$, tetapi relatif lebih sedikit jika 
dibandingkan dengan $\mathrm{N}$. Tingginya kandungan $\mathrm{Ca}$ tanah lapisan permukaan diduga berkaitan dengan mekanisme penyerapan dan pengembalian unsur hara melalui jatuhan serasah (bahan organik), yang ditunjukkan dengan tingginya konsentrasi Ca pada lapisan permukaan tanah.

Sumber Mg dalam tanah adalah mineral kelam (biotit, augit, horenblende, amfibol), garam $\left(\mathrm{MgSO}_{4}\right)$ dan kapur $\left(\mathrm{CaMg}\left(\mathrm{CO}_{3}\right)_{2}\right)$ (Hardjowigeno, 1987). Seperti halnya $\mathrm{N}, \mathrm{P}, \mathrm{K}$ dan $\mathrm{Ca}, \mathrm{Mg}$ memiliki kecenderungan yang sama, yaitu terjadi peningkatan jumlah $\mathrm{Mg}$ seiring dengan bertambahnya kedalaman, kecenderungan ini lebih disebabkan oleh BD dan tebal horison daripada oleh konsentrasi hara tanah.

\section{Berat Kering (Biomassa) Tegakan}

Biomassa tegakan hutan dipengaruhi oleh kerapatan tegakan dan kualitas tempat tumbuh (Satto dan Madgwick, 1982). Variasi nilai jumlah biomassa suatu tegakan terjadi karena adanya perbedaan kondisi dan perubahan-perubahan hubungan antara elemenelemen tanah - iklim - vegetasi (Ruhiyat, 1999). Berikut disajikan data biomassa komponen pohon penyusun tegakan.

Tabel 3. Berat Kering (Biomassa) Komponen Pohon Penyusun Tegakan

\begin{tabular}{cccccc}
\hline \multirow{2}{*}{$\begin{array}{c}\text { Umur } \\
\text { (Tahun) }\end{array}$} & Batang & $\begin{array}{c}\text { Cabang+ } \\
\text { Ranting }\end{array}$ & Daun & Kulit & \multirow{2}{*}{ Total } \\
\cline { 2 - 5 } 8 & 27,11 & 13,38 & 5,46 & 7,51 & 48,50 \\
& $(56 \%)$ & $(28 \%)$ & $(6 \%)$ & $(10 \%)$ & $(100 \%)$ \\
\hline
\end{tabular}

Pada Tabel 3 diketahui bahwa jumlah biomassa komponen batang merupakan komponen terbanyak penyusun tegakan, diikuti oleh komponen cabang+ranting, kulit dan daun. Secara umum komponen biomassa tegakan meningkat seiring dengan bertambahnya umur tegakan, kecuali komponen daun yang menurun dengan bertambahnya umur tegakan. Kecenderungan yang sama terjadi pada tegakan hutan tanaman Eucalytus deglupta di Kabupaten Paser, jumlah biomassa daun meningkat hingga umur 7 tahun dan menurun pada umur 9 tahun (Ruhiyat, 1993) dan pada tegakan sungkai di Kalimantan Tengah yang meningkat hingga umur 4 tahun dan menurun pada umur 5 tahun (Trisetiani, 2002).

Apabila dicermati hasil penghitungan persentasenya, diketahui bahwa batang memiliki porsi biomassa terbesar yaitu $56 \%$, diikuti oleh komponen cabang+ranting (28\%), kulit (10\%) dan daun (6\%). Besarnya porsi cabang+ranting tegakan jati merupakan salah satu faktor yang mempengaruhi jumlah relatif pada komponen lainnya, terutama untuk porsi batang. Jika dibandingkan dengan jenis tegakan HTI lainnya, yaitu Eucalytus deglupta ratarata sebesar $7-15 \%$ dan sengon sebesar $10-14 \%$ (Ruhiyat, 1993) serta tegakan sungkai sebesar $18-20 \%$ (Trisetiani, 2002), tegakan jati dalam penelitian ini memiliki percabangan yang lebih banyak. Hal ini kemungkinan dipengaruhi oleh faktor klimatis, genetis maupun perlakuan yang diberikan pada tegakan. Upaya peningkatan persentase batang masih 
sangat dimungkinkan dengan tindakan silvikultur, berupa pemangkasan dan penjarangan yang tepat.

\section{Kandungan Hara Tegakan}

Hasil penghitungan kandungan unsur hara yang berakumulasi dalam tegakan merupakan perkalian antara jumlah biomassa komponen pohon dalam tegakan (Tabel 3) dengan konsentrasi haranya (Tabel 4), sehingga kedua faktor itulah yang akan saling mempengaruhi besarnya kandungan hara biomassa tegakan (Tabel 5). Tabel tersebut sebagai berikut:

Tabel 4. Konsentrasi Hara Komponen Biomassa Jati

\begin{tabular}{cccccc}
\hline \multirow{2}{*}{ Komponen Biomassa } & \multicolumn{5}{c}{ Konsentrasi Hara Makro (\%) } \\
\cline { 2 - 6 } & $\mathbf{N}$ & $\mathbf{P}$ & $\mathbf{K}$ & $\mathbf{C a}$ & $\mathbf{M g}$ \\
\hline Batang (Tanpa Kulit) & 0,10 & 0,27 & 0,35 & 0,15 & 0,08 \\
Cabang+Ranting & 0,17 & 0,51 & 0,67 & 0,86 & 0,16 \\
Daun & 0,81 & 0,37 & 0,85 & 0,68 & 0,23 \\
Kulit & 0,16 & 0,49 & 0,86 & 1,87 & 0,32 \\
\hline
\end{tabular}

Pada Tabel 4 dapat diketahui bahwa berdasarkan komponennya, pola kecenderungan konsentrasi haranya adalah: komponen batang memiliki pola/ kecenderungan konsentrasi $\mathrm{K}>\mathrm{P}>\mathrm{Ca}>\mathrm{N}>\mathrm{Mg}$, pada komponen cabang+ranting $\mathrm{Ca}>\mathrm{K}>\mathrm{P}>\mathrm{N}>\mathrm{Mg}$, pada komponen daun berpola $\mathrm{K}>\mathrm{N}>\mathrm{Ca}>\mathrm{P}>\mathrm{Mg}$, sedangkan pada komponen kulit $\mathrm{Ca}>\mathrm{K}>\mathrm{P}>\mathrm{Mg}>\mathrm{N}$.

Apabila dilihat berdasarkan unsur haranya: $N$ memiliki pola daun>cabang+ranting $>$ kulit>batang. Konsentrasi $\mathrm{N}$ tertinggi berada pada daun, yaitu komponen yang paling banyak mengandung klorofil, diikuti oleh cabang+ranting dan kulit. Ketiga komponen ini merupakan komponen yang mengandung klorofil dan terendah pada komponen batang (tanpa kulit). Bagian tanaman yang berwarna hijau mengandung $\mathrm{N}$ protein lebih banyak dari komponen pohon lainnya (Rosmarkam dan Yuwono, 2001).

Konsentrasi unsur $\mathrm{P}$ memiliki pola cabang+ranting $>$ kulit $>$ daun $>$ batang. Umur tanaman dalam penelitian ini 8 tahun, yang mana merupakan fase generatif. Penyerapan $P$ pada fase generatif (90\%) lebih banyak daripada fase vegetatif (10\%) (Winarso, 2005) dan $P$ berperan vital dalam pembentukan bunga dan buah (Hanafiah, 2005).

Konsentrasi unsur K memiliki pola kulit>daun>cabang+ranting > batang. Seperti halnya $\mathrm{N}$, konsentrasi $\mathrm{N}$ relatif lebih tinggi beradapada komponen yang mengandung klorofil yaitu: kulit, cabang+ranting, daun. Hal tersebut terkait dengan peran penting $\mathrm{K}$ dalam proses fotosintesis, antara lain sebagai aktivator enzim (Winarso, 2005; Hanafiah, 2005).

Konsentrasi unsur $\mathrm{Ca}$ memiliki pola kulit>cabang+ranting $>$ daun $>$ batang. Konsentrasi Ca tertinggi pada komponen kulit juga dilaporkan oleh Fernandez-Moya et al (2013) pada tanaman jati di Amerika Tengah. Unsur Mg memiliki pola kulit>daun>cabang+ranting >batang. Kecenderungan konsentrasi Mg lebih banyak berada 
pada komponen yang mengandung klorofil, sejalan dengan fungsi Mg sebagai penyusun klorofil (Rosmarkam dan Yuwono, 2002; Hanafiah, 2005).

Dengan demikian dapat dikemukakan bahwa pada komponen berkayu (batang, cabang+ranting dan kulit) cenderung memiliki konsentrasi yang lebih tinggi untuk unsur $\mathrm{Ca}$, $\mathrm{K}$ dan $\mathrm{P}$, kecuali pada komponen daun. Berdasarkan unsur haranya $\mathrm{N}$ tertinggi terdapat pada komponen daun dan komponen berkayu yang masih berklorofil (cabang+ranting dan kulit), $\mathrm{P}$ dan $\mathrm{Ca}$ pada komponen cabang+ranting dan kulit, sedangkan $\mathrm{K}$ dan $\mathrm{Mg}$ konsentrasi tertinggi terdapat pada komponen kulit, daun dan cabang+ranting (komponen berklorofil). Kandungan unsur hara biomassa dapat dilihat pada Tabel 5 berikut ini.

Tabel 5. Kandungan Hara Biomassa Tegakan Jati

\begin{tabular}{cccccc}
\hline \multirow{2}{*}{ Komponen Biomassa } & \multicolumn{5}{c}{ Kandungan Hara (\%) } \\
\cline { 2 - 6 } & $\mathbf{N}$ & $\mathbf{P}$ & $\mathbf{K}$ & $\mathbf{C a}$ & $\mathbf{M g}$ \\
\hline Batang (Tanpa Kulit) & 2725,09 & 7357,74 & 9537,82 & 4087,64 & 2180,07 \\
Cabang+Ranting & 2275,28 & 6825,83 & 8967,26 & 11510,22 & 2141,44 \\
Daun & 2512,96 & 1147,90 & 2637,06 & 2109,65 & 713,56 \\
Kulit & 790,18 & 2419,93 & 4247,23 & 9235,26 & 1580,36 \\
\hline Total & 8303,51 & 17751,40 & 25389,37 & 26942,76 & 6615,43 \\
\hline
\end{tabular}

Dari Tabel 5 dapat diketahui bahwa secara keseluruhan total kandungan yang berakumulasi pada tegakan jati adalah $\mathrm{Ca}$, diikuti $\mathrm{K}, \mathrm{P}, \mathrm{N}$ dan $\mathrm{Mg}$. Dengan demikian dapat dikatakan bahwa jati menyerap unsur hara $\mathrm{Ca}$ yang terbesar. Kandungan $\mathrm{N}$ terbesar terdapat dalam komponen batang (33\%), diikuti daun (30\%), cabang+ranting (27\%), kulit (10\%). Unsur P terbanyak terdapat pada batang (41\%), diikuti cabang+ranting (38\%), kulit (14\%) dan daun (6\%). K terbanyak terdapat pada komponen batang (38\%), kemudian cabang+ranting, kulit (17\%) dan daun (10\%). Untuk Mg, terbanyak pada komponen batang (33\%), kemudian cabang+ranting (32\%) kulit (24\%) dan daun (11\%). Dengan demikian dapat dikatakan bahwa kecuali $\mathrm{N}$ persentase unsur basa $(\mathrm{P}, \mathrm{K}, \mathrm{Ca}, \mathrm{Mg})$ banyak terdapat pada komponen berkayu (batang, cabang+ranting dan kulit).

Unsur $\mathrm{P}, \mathrm{K}$ dan $\mathrm{Mg}$ terbanyak diakumulasikan pada komponen batang, diikuti komponen cabang+ranting, kulit dan daun. Unsur $\mathrm{N}$ dan Mg terbanyak pada komponen cabang+ranting, diikuti komponen batang, kulit dan daun. Berdasarkan hasil penghitungan tersebut dapat dikatakan bahwa unsur P, K, Ca dan Mg lebih banyak terakumulasi dalam batang, cabang+ranting dan kulit yang merupakan komponen berkayu, sedangkan untuk $\mathrm{N}$ terakumulasi dalam komponen batang, cabang+ranting dan daun. Dengan demikian perlu untuk mendapat perhatian lebih dari sisi pengelolaan unsur hara, yang mana unsur $\mathrm{P}, \mathrm{K}$, $\mathrm{Ca}, \mathrm{Mg}$ kemungkinan akan lebih besar hilang atau keluar dari sistem akibat pemanenan.

\section{Distribusi Hara Tanah - Tegakan}

Berdasarkan data mengenai jumlah unsur hara yang berakumulasi di dalam tanah (Tabel 2) dan tegakan (Tabel 5), maka dapat disusun informasi mengenai jumlah hara yang 
berakumulasi dalam sistem tanah-tegakan pada plot penelitian. Informasi tersebut disajikan dalam Gambar 1 berikut ini.

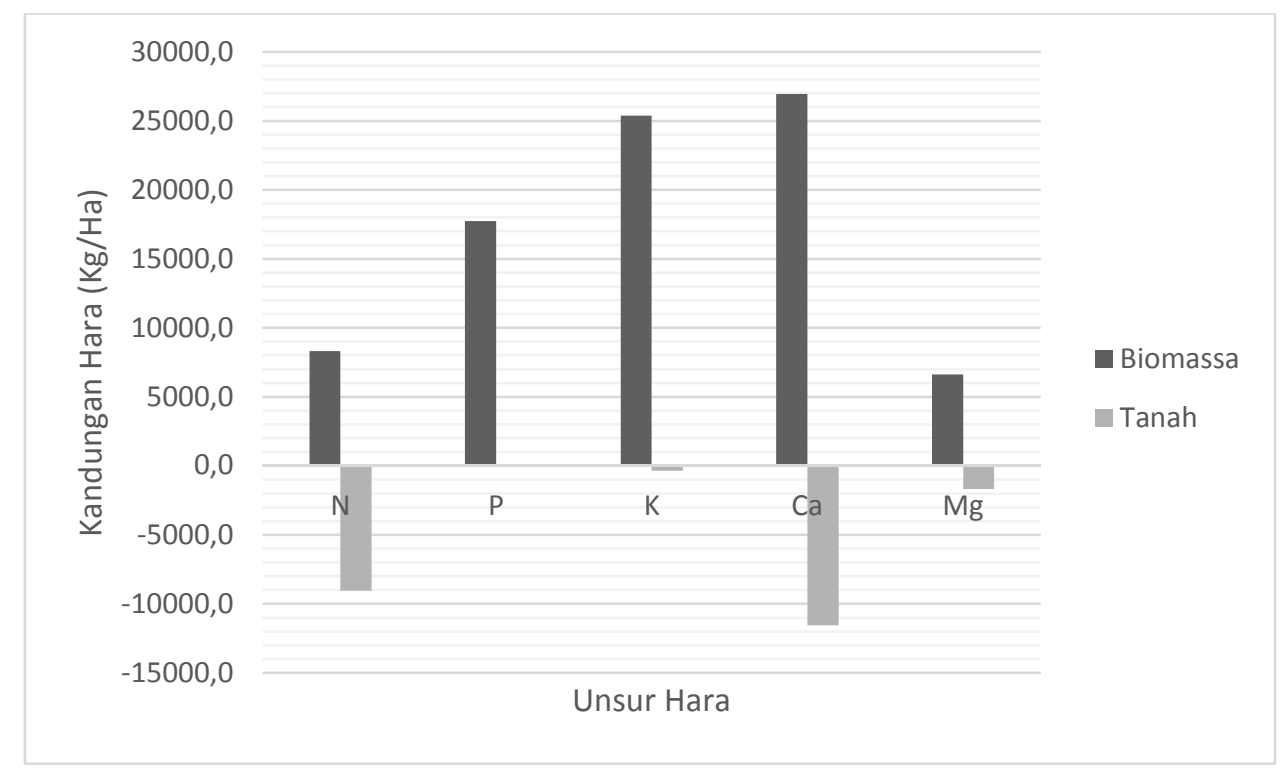

Gambar 1. Distribusi Hara Tanah-Tegakan

Berdasarkan Gambar 1 dapat dilihat bahwa dari kisaran porsi relatifnya, unsur hara $P$ pada plot penelitian (tegakan jati berumur 8 tahun) hampir seluruhnya berada pada tegakan $(99,8 \%)$, demikian juga dengan K $(98,7 \%)$ berada pada tegakan. Unsur berikutnya adalah $\mathrm{Mg}$, sebanyak $79,8 \%$ berada pada tegakan. Unsur Ca sebanyak $70 \%$ berada dalam tegakan, sedangkan N sebanyak $47,8 \%$ berada dalam tegakan. Dengan demikian dapat dikatakan bahwa unsur $\mathrm{P}$ dan $\mathrm{K}$ merupakan unsur hara yang paling kritis, unsur lainnya yang perlu mendapat perhatian adalah $\mathrm{Mg}$ dan $\mathrm{Ca}$. Unsur $\mathrm{N}$ cenderung lebih aman dibandingkan dengan unsur hara lainnya. Berdasarkan analasis data dalam penelitian ini adalah adanya tanaman jati memerlukan (menyerap) unsur hara yang banyak, sehingga apabila ditanam pada tanah dengan kandungan basa rendah perlu ditopang melalui pemupukan.

\section{Kesimpulan}

Secara umum unsur hara yang paling banyak berada di dalam tanah adalah $\mathrm{Ca}$, diikuti N, Mg, K dan paling sedikit P. Biomassa batang memiliki porsi terbesar (56\%), diikuti oleh komponen cabang+ranting (28\%), kulit (10\%) dan daun (6\%). Unsur P, K, Ca dan Mg lebih banyak terakumulasi dalam batang, cabang+ranting dan kulit (komponen berkayu), sedangkan unsur $\mathrm{N}$ terakumulasi dalam komponen batang, cabang+ranting dan daun. Unsur $\mathrm{P}$ dan $\mathrm{K}$ merupakan unsur hara yang paling kritis dibandingkan dengan unsur hara lainnya. Selain itu unsur hara yang perlu mendapat perhatian adalah $\mathrm{Ca}$ dan Mg. Unsur hara $\mathrm{N}$ hampir sebagian sudah berada di dalam tegakan.

Percabangan tegakan jati memiliki porsi cukup besar, oleh sebab itu diperlukan tindakan silvikultur, berupa pemangkasan dan penjarangan yang tepat. Tegakan jati dalam 
penelitian ini menyerap lebih banyak unsur $\mathrm{P}, \mathrm{K}, \mathrm{Ca}$ dan $\mathrm{Mg}$. Oleh sebab itu untuk pengembangan tanaman jati pada tanah dengan kandungan unsur $\mathrm{P}, \mathrm{K}, \mathrm{Ca}$ dan $\mathrm{Mg}$ rendah perlu didukung dengan pemupukan.

\section{Daftar Pustaka}

Anonim. (2010). Koordinator Nasional APFORGEN. Newsletter Edisi 1 Tahun 2010. Badan Pengembangan Kehutanan, Pusat Penelitian dan Pengembangan Peningkatan Produktivitas Hutan, Bogor.

Fernandez-Moya, J., R. Murillo, E. Portuguez, J.L. Fallas, V. Rios, F. Kottman, J.M. Verjans, R. Mata, \& A. Alvarado. (2013). Nutrient Concentration Age Dynamic of Teak (Tectona grandis L.f) Plantations in Central America. Forest System 22(1): 123-133

Hanafiah, K.A. (2005). Dasar-Dasar Ilmu Tanah. Edisi Pertama Cetakan Pertama. PT Raja Grafindo Persada, Jakarta.360 h.

Hardjowigeno, S. (1987). Ilmu Tanah. PT Mediyatama Sarana Perkasa, Jakarta. 218 h.

Imoro, Z.A., D.T. Dery, \& K.A. Kwadwo. (2012). Assesment of Soil Quality Improvement Under Teak and Albizia. Journal of Soil Science and Enviromental Management 3(4): 91-96.

Madgwick, H.A.I. (1976). Mensuration of Forest Biomassa. Oslo Biomass Study. University of Main at Orono, USA.

Marjenah. (2008). Prospek Budidaya Tanaman Jati di Kalimantan Timur. Disertasi. Program Studi IImu Kehutanan Universitas Mulawarman, Samarinda. $153 \mathrm{~h}$.

Marjenah. (2010). Budidaya Jati di Kalimantan Timur. Prospek Pembangunan Hutan Tanaman. Bimotry, Yogyakarta, $161 \mathrm{~h}$.

Murtinah, V, R. A. Marjenah, \& D. Ruhiyat. (2015). Pertumbuhan Hutan Tanaman Jati (Tectona grandis Linn.f) Di Kalimantan Timur. Jurnal Agrifor 15 (2): 287-292..

Odewumi, S.G, A.I. Iwara, \& F.O. Ogundel. (2013). Effect of Teak (Tectona grandis) Cultivation on Soil Physical and Chemical properties in Ajibode Community, Ibadan, Oyo State. Wudpecker Journal of Agriculture Research 2(2): 49-54.

Otomayo, A., O. Ogundele, \& I.S Akoteyon. (2010). Assesment of Soil Properties Under Teak Plantation in Abia-Badagry, Lagos, Nigeria. IJG 42(2): 105-118.

Rosmarkam, A \& N.W. Yuwono. (2001). Ilmu Kesuburan Tanah. Kanisius, Yogyakarta. 224 $\mathrm{h}$.

Ruhiyat, D. (1993). Pembangunan HTI: Menuju Produksi Maksimal yang Lestari, Evaluasi Kebutuhan Hara Tegakan Leda dan Sengon. GFG Report No. 22.

Ruhiyat, D. (1999). Potensi Tanah di Kalimantan Timur Karakteristik dan Strategi Pendayagunaannya. Pidato Pengukuhan Jabatan Guru Besar Madya dalam IImu Tanah Hutan pada Fakultas Kehutanan Universitas Mulawarman, Samarinda. 45 h.

Satto, T. \& H.A.I. Madgwick. (1982). Forestry Biomass. Martinus Nihjhoff, M. / Dr.W Junk Publishers the Hague / Boston / London. $151 \mathrm{~h}$.

Trisetiani, C. (2002). Evaluasi Kebutuhan dan Ketersediaan Hara Tegakan Hutan Tanaman Sungkai (Peronema canescens Jack.) di Areal HPHTI PT Pundiwana Semesta Kalimantan Tengah. Tesis. Program Studi IImu Kehutanan Universitas Mulawarman, Samarinda. 
Widyasasi, D. (2005). Evaluasi Kesesuaian Lahan Untuk Beberapa Jenis Tanaman HTI Pada Areal Rehabilitasi Hutan Bekas Kebakaran PT ITCI Kartika Utama. Tesis. Program Studi IImu Kehutanan Universitas Mulawarman, Samarinda. $141 \mathrm{~h}$. 